\title{
Studies of the effectiveness of gonadotrophin-releasing hormone, steroids and follicular fluid in modulating ovine gonadotrophin output in vivo and in vitro
}

\author{
K. M. Henderson, R. L. Ellen, L. C. Savage and K. P. McNatty \\ Wallaceville Animal Research Centre, MAFTech, Ministry of Agriculture and Fisheries, \\ PO Box 40063 Upper Hutt, New Zealand
}

\begin{abstract}
Summary. Gonadotrophin-releasing hormone (GnRH) readily stimulated LH output by sheep pituitary cells in vitro, and raised plasma LH concentrations in vivo in sheep, in a dose-dependent fashion. However, increases in FSH levels were only marginal by comparison. Dose-dependent decreases in sheep pituitary cell FSH output and in plasma FSH concentrations were caused by sheep follicular fluid and oestradiol-17 $\beta$ in vitro, and by bovine follicular fluid and oestradiol benzoate in vivo. In contrast, $\mathrm{LH}$ concentrations were only reduced slightly at the higher doses of these reagents. Cumulative suppressive effects of follicular fluid and oestradiol-17ß (oestradiol benzoate) on FSH levels were observed both in vitro and in vivo. The transient positive feedback effect of oestradiol benzoate on FSH output negated the suppressive effect of bovine follicular fluid on plasma FSH concentrations. Progestagens, androgens and catechol oestrogens also suppressed mean FSH output in vitro, though not as effectively as oestradiol- $17 \beta$. While only $1-5 \mathrm{pg} / \mathrm{ml}$ of oestradiol- $17 \beta$ was needed to suppress significantly mean FSH output in vitro, $>500 \mathrm{pg} / \mathrm{ml}$ of the other steroids was required. Seminal plasma inhibin-like peptide failed to suppress mean FSH output by cultured sheep pituitary cells at doses from $1 \mathrm{pg} / \mathrm{ml}$ to $500 \mathrm{ng} / \mathrm{ml}$. At higher doses, both FSH and LH output was suppressed and this was accompanied by morphological deterioration of the cells. It is suggested that, to raise plasma FSH concentrations with a view to increasing ovulation rates in sheep, the development of means to reduce the negative feedback effects of steroids, notably oestradiol-17 $\beta$, and inhibin on FSH secretion may be a more appropriate pharmacological strategy than increasing pituitary exposure to GnRH.
\end{abstract}

Keywords: pituitary; gonadotrophins; follicular fluid; steroids; GnRH; sheep

\section{Introduction}

The number of fertilizable ova shed at ovulation (i.e. ovulation rate) is a major determinant of prolificacy in sheep. Adequate exposure to both follicle-stimulating hormone (FSH) and luteinizing hormone $(\mathrm{LH})$ is essential for follicular maturation. Recent studies suggest that the low plasma FSH concentrations normally occurring during the preovulatory period may restrict the number of follicles which can attain ovulatory maturity in synchrony, and hence limit ovulation rate (Henderson \& McNatty, 1987; Henderson et al., 1988). Raising plasma FSH concentrations by infusion of low doses of purified FSH for $24 \mathrm{~h}$ in the $48 \mathrm{~h}$ before the onset of luteolysis, or for $48 \mathrm{~h}$ after the onset of luteolysis increases ovulation rates (McNatty et al., 1985; Henderson et al., 1988). In contrast ovulation rates are not increased above normal by raising plasma $\mathrm{LH}$ concentrations, either by infusion of purified LH (Henderson et al., 1988), or by infusion of GnRH (McNatty et al., 1981a). Ovulation rates can, however, be increased by injection of pharmacological amounts of 
human chorionic gonadotrophin, though this may be a consequence of contamination of the preparation with FSH-like activity (Radford et al., 1984). Gonadotrophin output is regulated by gonadotrophin-releasing hormone (GnRH), steroids and possibly inhibin. Several studies have focussed on the effects of these agents on sheep pituitary secretion of FSH and LH (Martin, 1984; Martin et al., 1986, 1988). The purpose of this study was to gain additional information in sheep on the relative effectiveness of these agents in modulating gonadotrophin output, particularly that of $\mathrm{FSH}$ in view of its importance in influencing ovulation rate.

\section{Materials and Methods}

\section{Animals and reagents}

Sheep. Parous New Zealand Romney ewes (aged 2.5-3.5 years and weighing $50-60 \mathrm{~kg}$ ) were used for this study. They were grazed on open pasture, and run with a vasectomized ram fitted with a marking harness to detect oestrous activity. The ewes were examined daily for signs of oestrus. In instances when ovariectomized ewes were required, ovaries were surgically removed at least 4 weeks, and no more than 9 weeks, before any experimental procedure (e.g. pituitary removal, in-vivo study) was performed. The minimum 4-week delay was to ensure completion of the major rise in plasma gonadotrophin concentrations which occurs after ovariectomy, and is indicative of the removal of ovarian feedback effects on the pituitary (Montgomery et al., 1987; McNatty et al., 1989).

Reagents. GnRH and seminal plasma inhibin-like peptide were obtained from Peninsula Laboratories Inc., Belmont, CA, USA. Oestradiol-17 $\beta$, $\beta$-oestradiol-3-benzoate, 2-hydroxy oestradiol, 4-hydroxy oestradiol, progesterone, testosterone, $5 \alpha$-dihydrotestosterone, sodium pyruvate, sodium bicarbonate, glutamine, gentamicin, collagenase (type IV), deoxyribonuclease I and ethylenediaminetetraacetic acid (EDTA) were obtained from Sigma Chemical Co., St Louis, MO, USA. Bovine serum albumin (BSA) was obtained from Immuno Chemical Products Ltd, Auckland, New Zealand; dispase from Boehringer Mannheim GmbH, Mannheim, W. Germany; amphotericin B from E. R. Squibb \& Son Inc., Princeton, NJ, USA; penicillin from Glaxo Laboratories Ltd, Greenford, UK, and Dulbecco's Modified Eagle Medium and non-essential amino acids from Gibco Laboratories, Grand Island, NY, USA. Hanks' balanced salt solution and calcium- and magnesium-free Dulbecco's phosphate buffered saline (DPBS) were prepared in our laboratory using salts of tissue culture grade. The $3 \alpha$-hydroxy and $3 \beta$-hydroxy-4-pregnen-20-one were a gift from Dr J. Wiebe, University of Western Ontario, London, Canada. The sheep FSH radioimmunoassay kit and sheep LH preparations (NIDDK-oLH-I-3 and NIDDK-oLH-24) were gifts from the National Institute of Diabetes and Digestive and Kidney Diseases, National Hormone and Pituitary Program, University of Maryland, USA.

Follicular fluid is rich in inhibin activity and obtained relatively easily, and so provides a convenient crude inhibin preparation. Single batches of bovine (b) and ovine (o) follicular fluid (FF) were prepared for this study. The oFF was used to investigate inhibin activity in pituitary cultures in vitro, and the bFF was used to investigate inhibin activity in the in-vivo studies. (The large amounts of FF required for the in-vivo studies made it impractical to use oFF.) Ovaries were obtained from cows and sheep slaughtered at a local abattoir. Antral follicles on the surface of the ovaries were punctured with a 20-gauge needle, and the FF aspirated. Debris and red blood cells were removed from pooled fluids by centrifugation at $1200 \mathrm{~g}$ for $15 \mathrm{~min}$ at $4^{\circ} \mathrm{C}$, and the supernantant was stored frozen at $-20^{\circ} \mathrm{C}$. Several collections of FF were subsequently thawed, and the steroids removed by treatment with dextran T-70 $(0 \cdot 1 \%$, Pharmacia Fine Chemicals AB, Uppsala, Sweden) -coated charcoal (Norit A, 1\%, Fisher Scientific Co., Springfield, New Jersey, USA) as described previously (Henderson et al., 1986). The FF was then stored in aliquants at $-20^{\circ} \mathrm{C}$ until needed.

A single batch of serum for use in the pituitary cell culture medium was obtained from ovariectomized ewes. Four ewes which had been ovariectomized 1 month previously were exsanguinated under anaesthesia through a catheter inserted into the jugular vein. The blood was allowed to clot and the serum collected and stored frozen at $-20^{\circ} \mathrm{C}$. After checking that none of the 4 sera were toxic to pituitary cells in culture, the sera were pooled and treated with dextran T-70 $(0.01 \%)$-coated charcoal $(0.1 \%)$ as for the FF samples. The pooled sera were then stored at $-20^{\circ} \mathrm{C}$ in $100 \mathrm{ml}$ samples until needed.

\section{Pituitary cell cultures}

Pituitaries were recovered from sheep (usually 2 sheep at a time) immediately after their slaughter at Wallaceville, and placed in chilled Hanks' Balanced Salt Solution containing $1 \%$ bovine serum albumin, gentamicin $(50 \mu \mathrm{g} / \mathrm{ml})$, amphotericin B $(2.5 \mu \mathrm{g} / \mathrm{ml})$ and penicillin $(100 \mathrm{units} / \mathrm{ml}), \mathrm{pH} 7.4$ (HBSS). The pituitaries were washed several times with HBSS, and the posterior pituitary and any extraneous tissue was dissected off and discarded. Remaining anterior pituitary was thinly sliced and placed into $50 \mathrm{ml}$ of pre-warmed $\left(37^{\circ} \mathrm{C}\right) \mathrm{HBSS}$ containing $25 \mathrm{mg}$ collagenase, $50 \mathrm{mg}$ dispase and $50 \mu \mathrm{g}$ deoxyribonuclease $1, \mathrm{pH} 7.4$, and incubated with shaking for $45 \mathrm{~min}$ at $37^{\circ} \mathrm{C}$. The enzyme solution was then replaced with $50 \mathrm{ml}$ DPBS with added BSA $(1 \%)$ and $2 \mathrm{~mm}$-EDTA, pH 7.4 , and the incubation continued for a further $10 \mathrm{~min}$ at $37^{\circ} \mathrm{C}$ with shaking. The tissue fragments were washed 5 times with DPBS and then dispersed by repeatedly drawing gently through the tip of a Pasteur pipette, and a series of needles (18-20 gauge) attached to a 1 or 
$2 \mathrm{ml}$ syringe. As the cells were released they were transferred into HBSS. The collected cells were centrifuged at $200 \mathrm{~g}$ for $10 \mathrm{~min}$, washed with HBSS and centrifuged again at $200 \mathrm{~g}$ for $10 \mathrm{~min}$. The cells were finally resuspended in Dulbecco's Modified Eagle Medium containing 10\% dextran-coated charcoal-treated ovariectomized sheep serum, glutamine $(1 \%)$, non-essential amino acids, sodium pyruvate $(1 \mathrm{mM})$, sodium bicarbonate $(3 \cdot 7 \mathrm{~g} / \mathrm{l})$, gentamicin $(50 \mu \mathrm{g} / \mathrm{ml})$, amphotericin B $(2.5 \mu \mathrm{g} / \mathrm{ml})$ and penicillin $(100 \mathrm{units} / \mathrm{ml}), \mathrm{pH} 7.4(\mathrm{DCM})$. The cells were counted using a haemocytometer, and the volume of DCM was adjusted to give $0.5-1 \times 10^{6}$ cells $/ \mathrm{ml}$. Samples of $1 \mathrm{ml}$ were pipetted into individual round wells ( $16 \mathrm{~mm}$ diam.) of multi-welled tissue-culture dishes (Nunc, Kamstrup, Denmark) and incubated for $24 \mathrm{~h}$ at $37^{\circ} \mathrm{C}$ in an humidified atmosphere of $5 \% \mathrm{CO}_{2}$ in air. During this time the cells attached to the bottom of the wells. The medium was then replaced with fresh DCM $(1 \mathrm{ml})$ with or without added GnRH, FF, inhibin-like peptide or steroids. Four replicated cultures for each dose of each treatment were normally established, and some treatments were repeated on separate occasions. The cells were incubated for a further $72 \mathrm{~h}$ with the medium being renewed every $24 \mathrm{~h}$. The spent media were stored frozen at $-20^{\circ} \mathrm{C}$. At the end of the culture period, the cells were washed thoroughly with saline and stored frozen until assayed for protein by the method of Lowry et al. (1951), using bovine serum albumin as the protein standard.

\section{Studies in vivo}

Treatment with GnRH. On the day before treatment with GnRH 16 ovariectomized ewes, and on a separate occasion, 2 months later, 16 intact ewes at Day 9 of the oestrous cycle (Day $0=$ day of oestrus), were penned indoors and each fitted with an intrajugular cannula for subsequent blood sampling and administration of GnRH. The next day, 2-3-ml blood samples were taken from each ewe at 30-min intervals for $4 \mathrm{~h}$. GnRH was then administered intravenously in $1 \mathrm{ml}$ saline at doses of $0,0.5,5$ and $50 \mu \mathrm{g}$ ( 4 ewes/group). Blood samples were taken every $10 \mathrm{~min}$ for $1 \mathrm{~h}$, every $30 \mathrm{~min}$ for the next $2 \mathrm{~h}$ and hourly for the next $5 \mathrm{~h}$. The cannulae were then removed and the ewes returned to pasture.

Treatment with bFF and oestradiol benzoate. Ovariectomized ewes were penned indoors: 20 ewes received 5 intramuscular injections at 12 -h intervals (starting at $0 \mathrm{~h}$ ) of bFF ( 5 or $10 \mathrm{ml})$, oestradiol benzoate $(50$ or $500 \mu \mathrm{g}$ given in $1 \mathrm{ml}$ vegetable oil) or $50 \mu \mathrm{g}$ oestradiol benzoate plus $5 \mathrm{ml} \mathrm{bFF} \mathrm{(4} \mathrm{ewes/group),} \mathrm{and} \mathrm{the} \mathrm{remaining} 4$ ewes served as controls. Blood samples ( $2-3 \mathrm{ml})$ were taken by venepuncture from all ewes at $-8,-4,0,12,16,20,36,40,44$ and $60 \mathrm{~h}$.

\section{Radioimmunoassays}

Gonadotrophin concentrations in plasma and culture medium were measured by specific radioimmunoassays. FSH was measured using the sheep FSH radioimmunoassay kit and protocol provided by the National Hormone and Pituitary Program, NIDDK, University of Maryland, USA (Technical Report No. 141). The FSH antiserum was NIAMDD-anti-oFSH-1 (AFP-C5288113) and it was used at a final tube dilution of 1:80000 in a total assay incubation volume of $0.5 \mathrm{ml}$. The sheep FSH for iodination was NIAMDD-oFSH-I-1 (AFP-5679C) and the reference preparation was NIAMDD-oFSH-RP-1 (biopotency $75 \times$ NIH-FSH-SI). The sensitivity of the assay was $0.05-0.1 \mathrm{ng}$ per assay tube and the intra- and inter-assay coefficients of variation were $<10 \%$. LH was measured using the specific radioimmunoassay described previously (McNatty et al., 1981b). The antiserum used was generated in a rabbit against NIH-LH-S1 I and was used at an initial dilution of 1:40 000. This LH antiserum exhibited low crossreactions with other pituitary hormones: sheep prolactin (NIH-P-S12) $0.09 \%$; sheep thyroid stimulating hormone (NIH-TSH-S 8 ) 2.4\%; sheep growth hormone (NIH-GH-S11) $0.4 \%$ and sheep FSH (NIH-FSH-S10) $0.4 \%$. The pituitary LH reference preparation was NIADDK-oLH-24 and the iodinated tracer was NIADDK-oLH-I-3. The sensitivity of the assay was $0.025-0.05 \mathrm{ng}$ per assay tube, and the intra- and inter-assay coefficients of variation were $<11 \%$.

\section{Data analysis}

Gonadotrophin output by all cell cultures (except for those of Fig. 7) was initially standardized with respect to the protein content of the pituitary cells at the end of the culture period. There was, however, considerable variation (up to 6-fold) in gonadotrophin output by equivalent pituitary cultures established on separate occasions. To compensate for this variation, when treatments were repeated on separate occasions (as for data in Figs I and 3), mean gonadotrophin output by treated cultures on each occasion was expressed as a percentage of the mean output by the appropriate control (zero dose) cultures also established on each occasion. Mean percentage values for each treatment were then calculated.

There was also considerable variation between individual sheep in plasma gonadotrophin concentrations before any treatment. To compensate for this between-sheep variation, plasma gonadotrophin concentrations for each ewe following the start of a treatment were expressed as a percentage of the mean pretreatment value. Mean percentage values for each treatment group of ewes were then calculated.

Analysis of variance in conjunction with the Newman-Keuls multiple range test was used to test for statistically significant differences between mean values. The level of significance was set at $P<0.05$. 

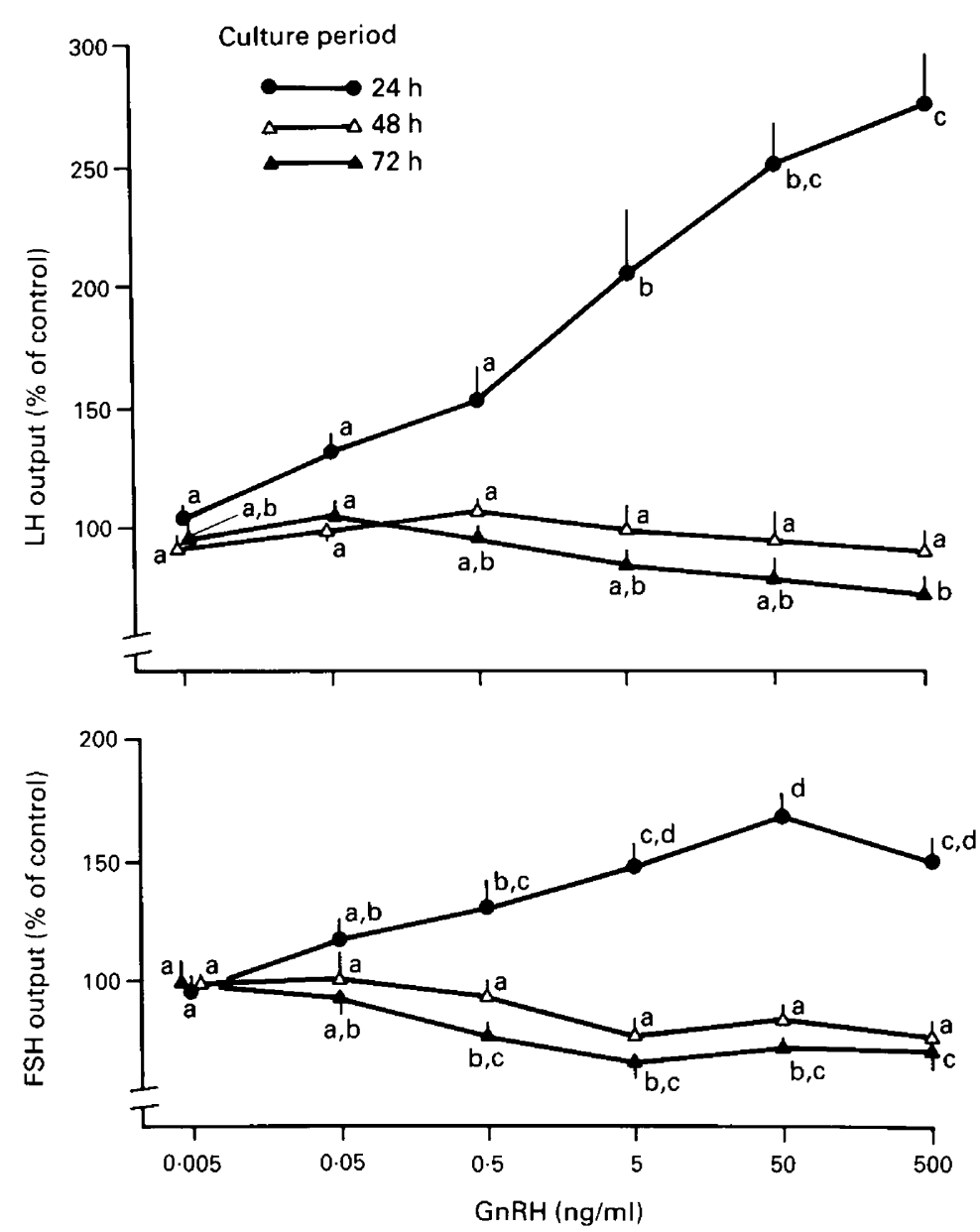

Fig. 1. Effect of GnRH on LH and FSH output by pituitary cells from ovariectomized ewes. The results were derived from 4 replicate experiments. In each experiment mean gonadotrophin output by GnRH-treated cultures was expressed as a percentage of the mean output by control (zero dose) cultures. FSH and LH output by control cultures ranged from 370 to $1185 \mathrm{ng}$ $\mathrm{FSH} / \mathrm{mg}$ protein and from 1 to $6 \mu \mathrm{g} \mathrm{LH} / \mathrm{mg}$ protein. Mean percentage values for the 4 replicate experiments were calculated, and these are presented with vertical lines showing the s.e.m. Mean values not sharing a common letter superscript for the same culture period are significantly different $(P<0.05)$.

\section{Results}

\section{Effect of GnRH on gonadotrophin output}

Figure 1 shows the effect of increasing concentrations of GnRH on LH and FSH output in vitro by pituitary cells from ovariectomized ewes. A dose-dependent increase in mean LH and FSH output occurred during the first $24 \mathrm{~h}$ of culture. However, while mean LH output was increased by up to about 3-fold, mean FSH output was only increased about 1-5-fold. During the 2nd and 3rd days of culture, mean gonadotrophin output generally remained at control (zero dose) levels or in some instances, at the higher concentrations of $\mathrm{GnRH}$, fell significantly. The relative insensitivity of FSH output to stimulation by GnRH was not peculiar to cells from ovariectomized ewes. 

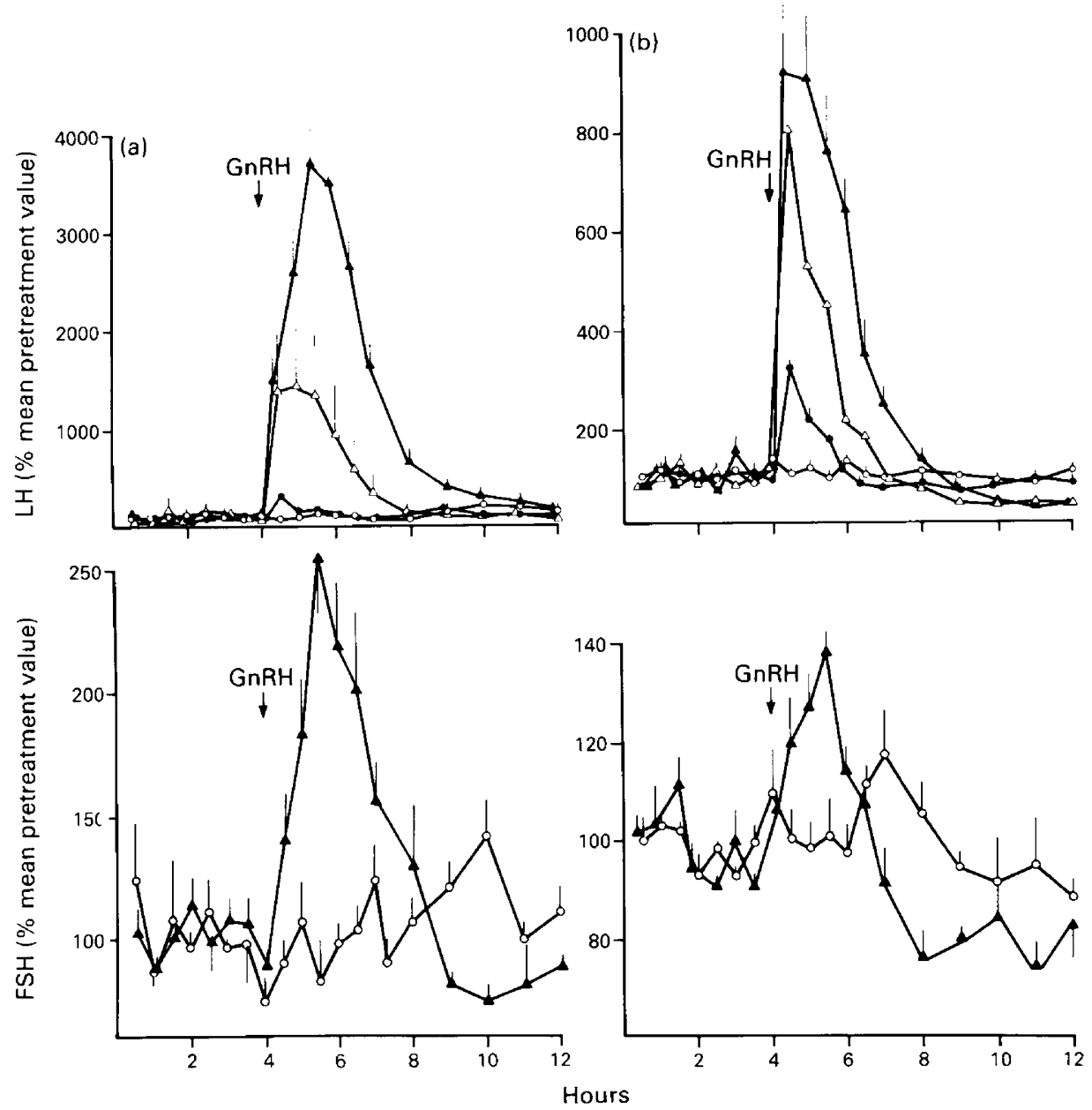

Fig. 2. Effect of GnRH on plasma gonadotrophin concentrations in (a) intact and (b) ovariectomized ewes. For each ewe, plasma gonadotrophin concentrations were expressed as a percentage of the mean concentration before injection of $\mathrm{GnRH}$. (These mean concentrations ranged from 0.7 to $2.3 \mathrm{ng} \mathrm{FSH} / \mathrm{ml}$ and 0.3 to $0.8 \mathrm{ng} \mathrm{LH} / \mathrm{ml}$ for intact ewes, and from 8 to $20 \mathrm{ng}$ $\mathrm{FSH} / \mathrm{ml}$ and 3.6 to $10.5 \mathrm{ng} \mathrm{LH} / \mathrm{ml}$ for ovariectomized ewes.) Mean percentage values for each treatment group of 4 ewes were then calculated. These mean values have been presented with vertical lines showing the s.e.m. when larger than the size of the symbol. $\bigcirc, \boldsymbol{\bullet}, \Delta$, and $\boldsymbol{\Delta}$ refer to groups of ewes receiving $0,0 \cdot 5,5$ and $50 \mu \mathrm{g} \mathrm{GnRH}$, respectively. FSH data for ewes receiving 0.5 and $5 \mu \mathrm{g} \mathrm{GnRH}$ are not shown because the mean FSH values did not differ significantly from those of ewes receiving $0 \mu \mathrm{g} \mathrm{GnRH}$.

Similar findings were also obtained in a single culture experiment with cells from an intact ewe at Day 10 of the oestrous cycle. During the first $24 \mathrm{~h}$ of culture, mean LH output increased in a dosedependent fashion up to 4.8-fold above control (zero dose) cultures in response to $50 \mathrm{ng} \mathrm{GnRH}$; mean FSH output only increased 1.2-fold. By Day 3 of culture, mean LH and FSH output in response to $50 \mathrm{ng} \mathrm{GnRH}$ was only 85 and $72 \%$ respectively of that of the control (zero dose) cultures. Similar differences in LH and FSH output in response to GnRH were also apparent in vivo. Figure 2 shows the effect of a single injection of several doses of GnRH on plasma gonadotrophin concentrations (expressed as a percentage of pretreatment values) in intact (Day 10) and 

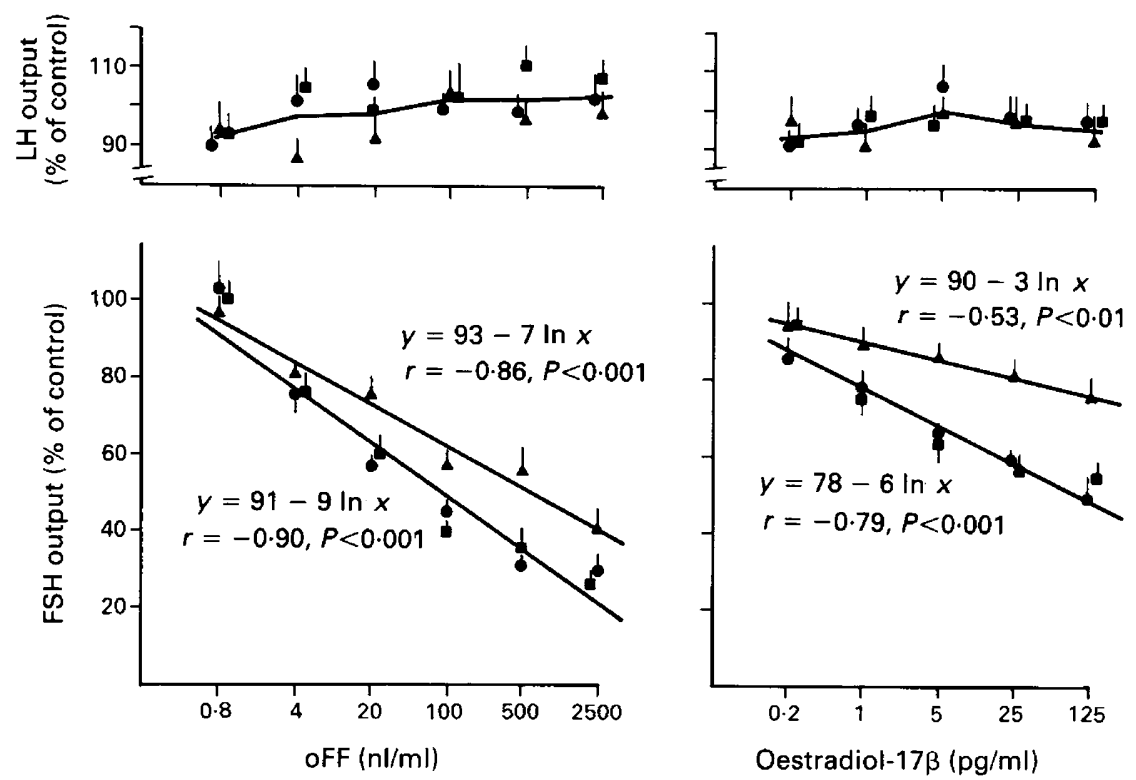

Fig. 3. Effect of increasing doses of oFF and oestradiol- $17 \beta$ on gonadotrophin output by pituitary cells from ovariectomized ewes during 3 days of culture. $\boldsymbol{\Delta}, \boldsymbol{a n d}$ refer to Days 1 , 2 and 3 of culture respectively. The results were derived from 7 replicate experiments. For each experiment, mean gonadotrophin output by treated cultures was expressed as a percentage of the mean output by the appropriate control (zero dose) cultures. FSH and LH output by the control cultures ranged from 220 to $1400 \mathrm{ng} \mathrm{FSH} / \mathrm{mg}$ protein and from 0.9 to $11 \mu \mathrm{g} \mathrm{LH} / \mathrm{mg}$ protein. Mean percentage values for the 7 replicate experiments were calculated and these are presented with vertical lines showing the s.e.m. Linear regression lines have been fitted to the FSH data for Day 1, and the pooled FSH data for Days 2 and 3. The associated regression equations are also shown, together with the correlation coefficients $(r)$ and significance. The mean LH percentage values for the 3 days of culture at each dose of oFF and oestradiol-17 $\beta$ have been joined by straight lines.

ovariectomized ewes. GnRH increased mean plasma $\mathrm{LH}$ values in a dose-dependent fashion in both intact and ovariectomized ewes. However, mean FSH levels were only increased at the highest dose of $\mathrm{GnRH}(50 \mu \mathrm{g})$. In intact ewes, $50 \mu \mathrm{g} \mathrm{GnRH}$ increased mean peak LH concentrations by about 40 -fold (from $0.6 \pm 0.2$ to $23.3 \pm 3.7 \mathrm{ng} / \mathrm{ml}$, mean \pm s.e.m.), but mean peak FSH concentrations by only about 2.5 -fold (from $1.5 \pm 0.2$ to $3.8 \pm 0.5 \mathrm{ng} / \mathrm{ml}$ ). Similarly, in ovariectomized ewes, $50 \mu \mathrm{g} \mathrm{GnRH}$ increased mean peak LH concentrations by about 10 -fold (from $4.9 \pm 0.7$ to $45 \cdot 1 \pm 8 \cdot 5 \mathrm{ng} / \mathrm{ml}$ ), but mean peak FSH concentrations by only about $1 \cdot 3$-fold (from $11 \cdot 8 \pm 2 \cdot 0$ to $15 \cdot 8 \pm 2 \cdot 3 \mathrm{ng} / \mathrm{ml}$ ).

\section{Effect of oFF and oestradiol-17\% on gonadotrophin output in vitro}

Ovine FF and oestradiol-17 $\beta$ caused a dose-dependent decrease in mean FSH output by cultured pituitary cells from ovariectomized ewes on each day of culture (Fig. 3). In contrast, mean LH output changed little, and fluctuated around $90-110 \%$ of that produced by control (zero dose) cultures, over the whole culture period.

Figure 4 shows FSH output by cells from ovariectomized ewes after 1 and 2 days of culture with oestradiol- $17 \beta(0,5$ and $125 \mathrm{pg} / \mathrm{ml})$ and oFF $(0,0 \cdot 1$ and $2 \cdot 5 \mu \mathrm{l} / \mathrm{ml})$ either alone or in combination. On both days of culture, oFF and oestradiol-17 $\beta$ significantly suppressed mean FSH output on their own. On Day 1, oestradiol-17 $\beta$ and oFF in combination suppressed mean FSH output to 


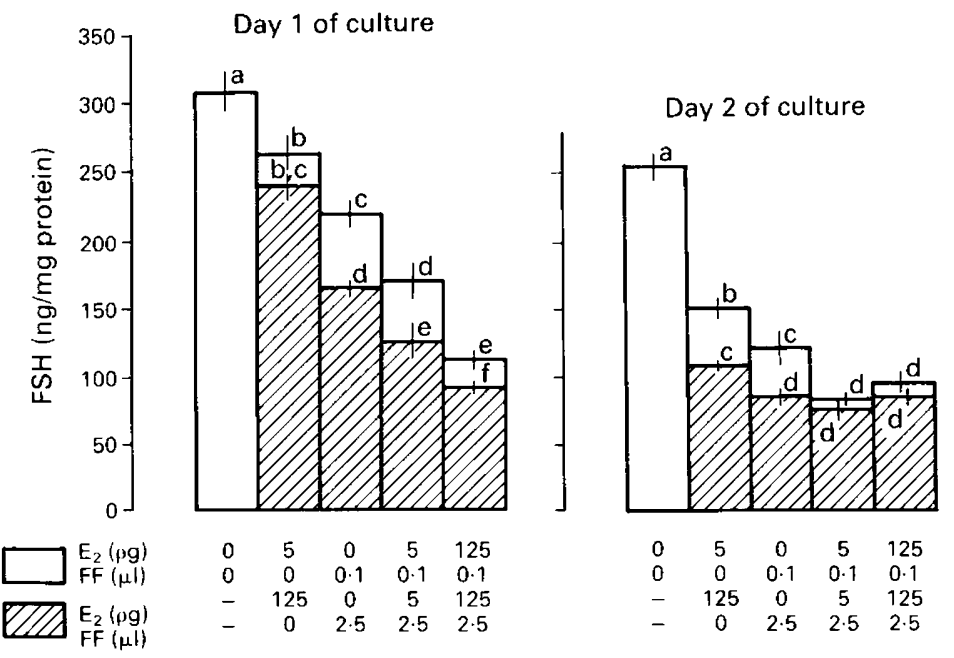

Fig. 4. Effect of oFF $(0 \cdot 1$ and $2 \cdot 5 \mu \mathrm{l} / \mathrm{ml})$ and oestradiol- $17 \beta\left(\mathrm{E}_{2}, 5\right.$ and $\left.125 \mathrm{pg} / \mathrm{ml}\right)$ alone and together on FSH output by pituitary cells from ovariectomized ewes. Values are means of 5 replicate cultures with vertical lines showing the s.e.m. Mean values with different letter superscripts on the same day are significantly different $(P<0.05)$.

levels significantly lower than when either was given alone. On Day 2, mean FSH output by cells cultured with $0 \cdot 1 \mu \mathrm{loFF}$ plus 5 or $125 \mathrm{pg}$ oestradiol- $17 \beta$ was reduced to the levels produced by cells receiving $2 \cdot 5 \mu \mathrm{oFF}$ alone. However, no further significant reduction in mean FSH output was obtained by culturing with $2 \cdot 5 \mu \mathrm{l}$ oFF plus 5 or $125 \mathrm{pg}$ oestradiol-17 $\beta$.

\section{Effect of bFF and oestradiol benzoate on plasma concentrations of FSH and LH}

Ovariectomized ewes were injected with bFF $(0,5$ or $10 \mathrm{ml})$, oestradiol benzoate $(0,50$ or $500 \mu \mathrm{g})$ or bFF and oestradiol benzoate $(5 \mathrm{ml}$ and $50 \mu \mathrm{g}$ ) at $12-\mathrm{h}$ intervals for $48 \mathrm{~h}$. Figure 5 shows plasma concentrations (expressed as a percentage of pretreatment values) of FSH and LH 12, 20, 40 and $60 \mathrm{~h}$ after the first injection. Both bFF and oestradiol benzoate caused a dose-dependent decrease in FSH concentrations. The mean \pm s.e.m. plasma FSH concentrations at $60 \mathrm{~h}$ following treatment with the higher doses of bFF and oestradiol benzoate were $1.3 \pm 0.3$ and $1.9 \pm 0.4 \mathrm{ng} / \mathrm{ml}$ respectively, which were similar to the mean plasma FSH values before ovariectomy of the ewes $(1.4 \pm 0.3 \mathrm{ng} / \mathrm{ml})$. At 12,40 and $60 \mathrm{~h}$, mean FSH concentrations in ewes receiving bFF $(5 \mathrm{ml})$ and oestradiol benzoate $(50 \mu \mathrm{g})$ together were significantly lower than in ewes receiving either dosage alone, but were generally similar to those of ewes receiving injections of $10 \mathrm{ml} b F F$ or $500 \mu \mathrm{g}$ oestradiol benzoate (Fig. 5). Although mean FSH concentrations were significantly reduced at $20 \mathrm{~h}$ after treatment with bFF alone, this reduction was negated in ewes receiving bFF plus oestradiol benzoate, the values being similar to those of ewes receiving oestradiol benzoate alone. A positive feedback effect of oestradiol benzoate resulting in increased plasma LH concentrations was also apparent at $20 \mathrm{~h}$. At the other times, LH concentrations were unaffected by bFF or oestradiol benzoate.

\section{Effect of progestagens, androgens and catechol oestrogens on FSH output in vitro}

Androstenedione, 5 $\alpha$-dihydrotestosterone, progesterone, 3 $\alpha$-hydroxy-4-pregnen-20-one, 2hydroxy oestradiol and 4-hydroxy oestradiol each significantly suppressed mean FSH output by 

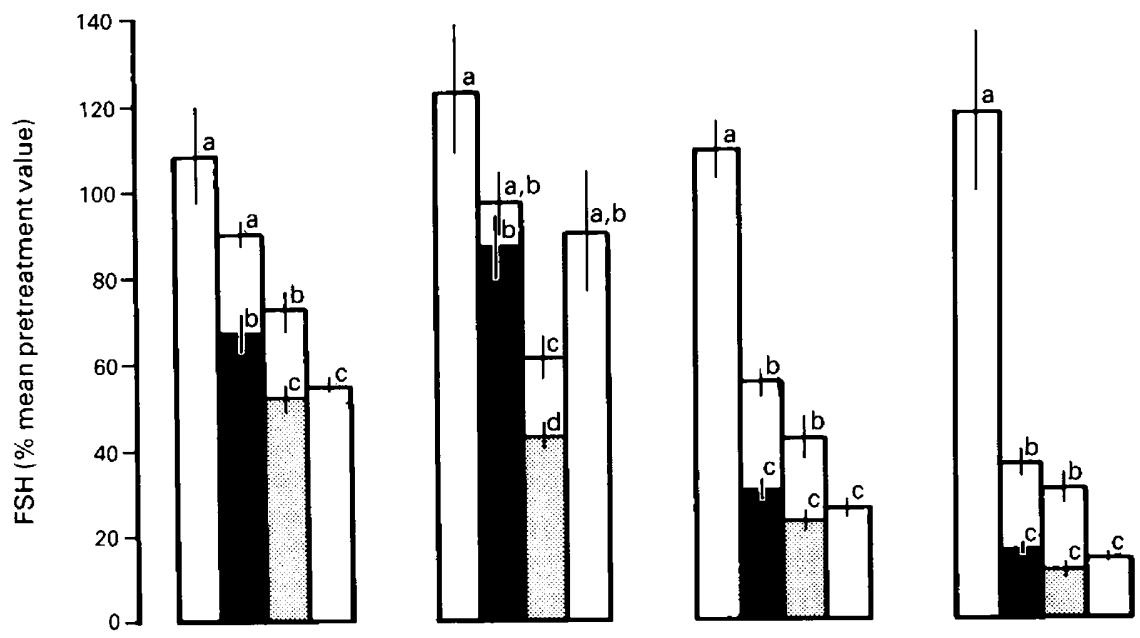

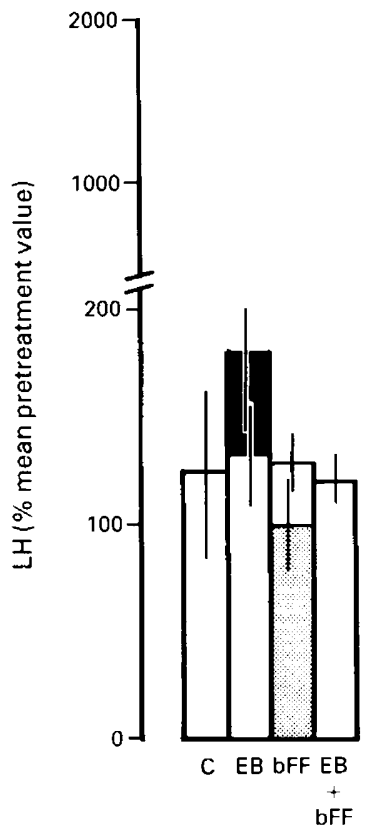

$12 \mathrm{~h}$

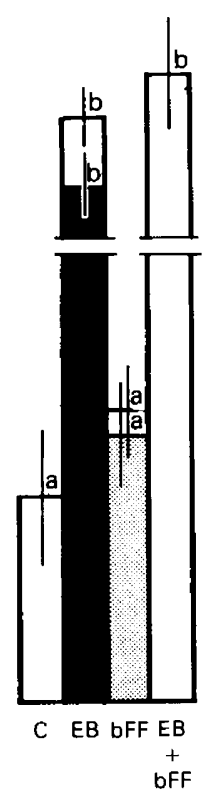

$20 \mathrm{~h}$

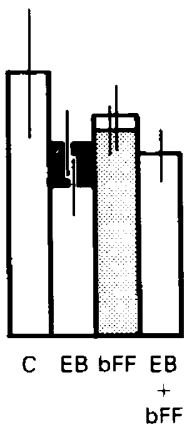

$40 \mathrm{~h}$

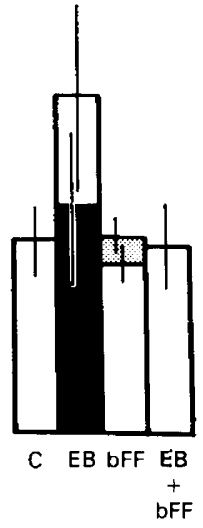

$60 \mathrm{~h}$

Fig. 5. Effect of $b F F$ and oestradiol benzoate (EB) alone and in combination on plasma gonadotrophin concentrations in ovariectomized ewes. C, control (zero dose); EB, $\square 50 \mu \mathrm{g}$, $500 \mu \mathrm{g}$; bFF, $\square 5 \mathrm{ml}$, $10 \mathrm{ml} ; 5 \mathrm{ml}$ bFF $+50 \mu \mathrm{g} \mathrm{EB}, \square$. For each ewe, plasma gonadotrophin concentrations were expressed as a percentage of the mean pretreatment value, and these ranged from 11.2 to $16.5 \mathrm{ng} \mathrm{FSH} / \mathrm{ml}$ and 3.4 to $4.7 \mathrm{ng} \mathrm{LH} / \mathrm{ml}$. Mean percentage values for each group of 4 ewes were calculated and these are presented with vertical lines showing the s.e.m. Mean values not sharing a common letter superscript within the same time period differ significantly $(P<0 \cdot 05)$. Groups of mean values without superscripts are not significantly different. 

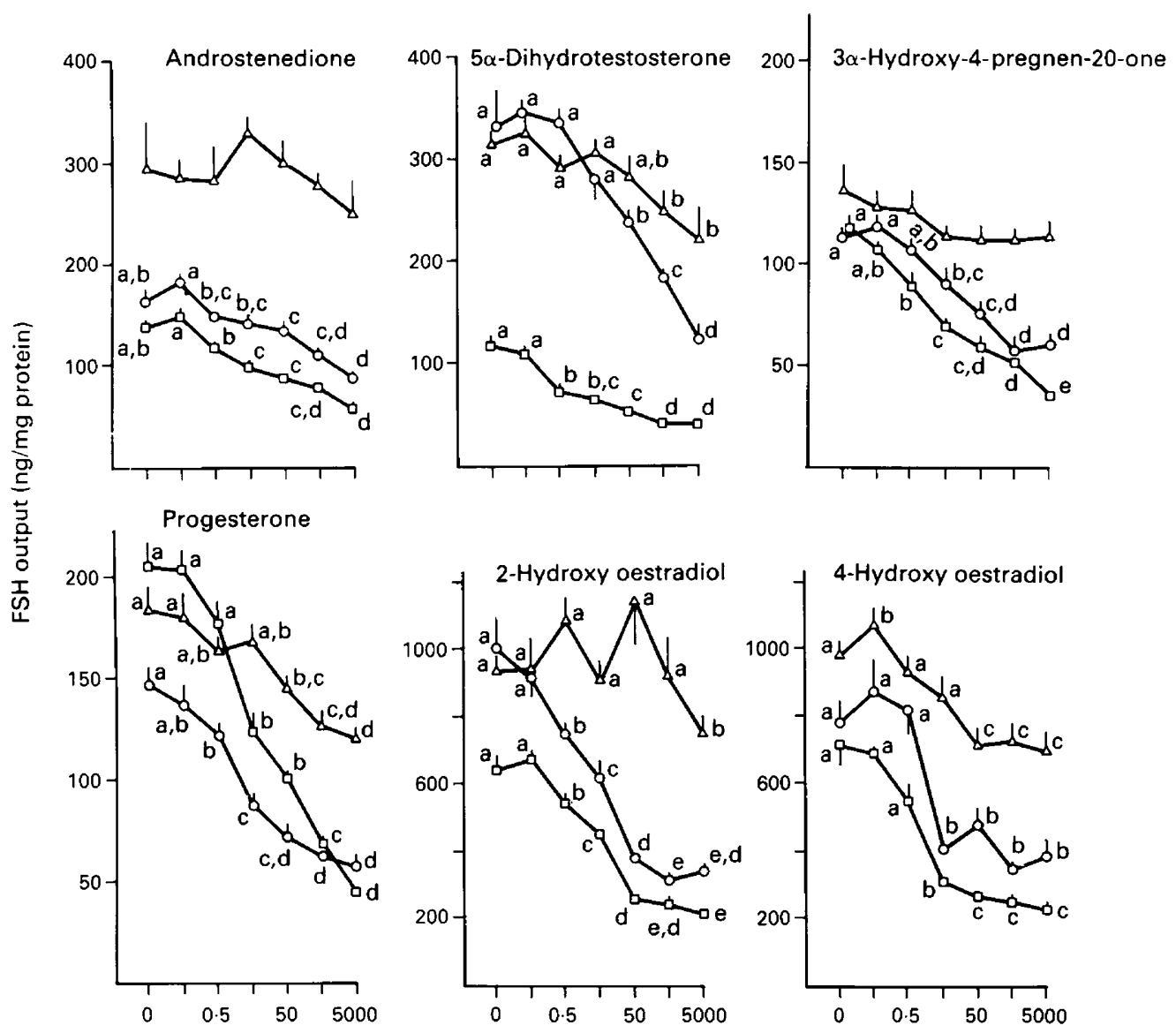

Steroid conc. (ng/ml)

Fig. 6. Effect of steroids on FSH output by cultured pituitary cells from ovariectmized ewes. Values are means of 4 replicate cultures with vertical lines showing the s.e.m. when larger than the size of the symbol. Mean values not sharing a common letter superscript over the same time period are significantly different $(P<0.05)$. Groups of mean values without superscripts are not significantly different. $\triangle, O$ and $\square$ refer to Days 1,2 and 3 of culture with steroid respectively.

cells from ovariectomized ewes in a dose-dependent manner (Fig. 6). Inhibition was observed from Day 1 of treatment with all of the steroids except for androstenedione and $3 \alpha$-hydroxy-4pregnen-20-one with which significant inhibition was observed only on Days 2 and 3. Effects similar to those of $5 \alpha$-dihydrotestosterone and $3 \alpha$-hydroxy-4-pregnen-20-one were also observed with testosterone and 3 3 -hydroxy-4-pregnen-20-one respectively (data not shown). However, in contrast to the inhibitory effects of oestradiol-17 $\beta$ on mean FSH output, for which inhibition was observed at doses as low as $1-5 \mathrm{pg} / \mathrm{ml}$ (Fig. 3), significant suppression of FSH by the above-mentioned steroids was not observed at doses of $<500 \mathrm{pg} / \mathrm{ml}$. It is unlikely that the suppression of FSH output by these high doses of steroids was a consequence of their contamination with oestradiol-17ß; no such contamination was evident on their analysis by highpressure liquid chromatography (Waters \& Bondapak C18 column; acetonitrile:water (60:40 v/v) as mobile phase). 

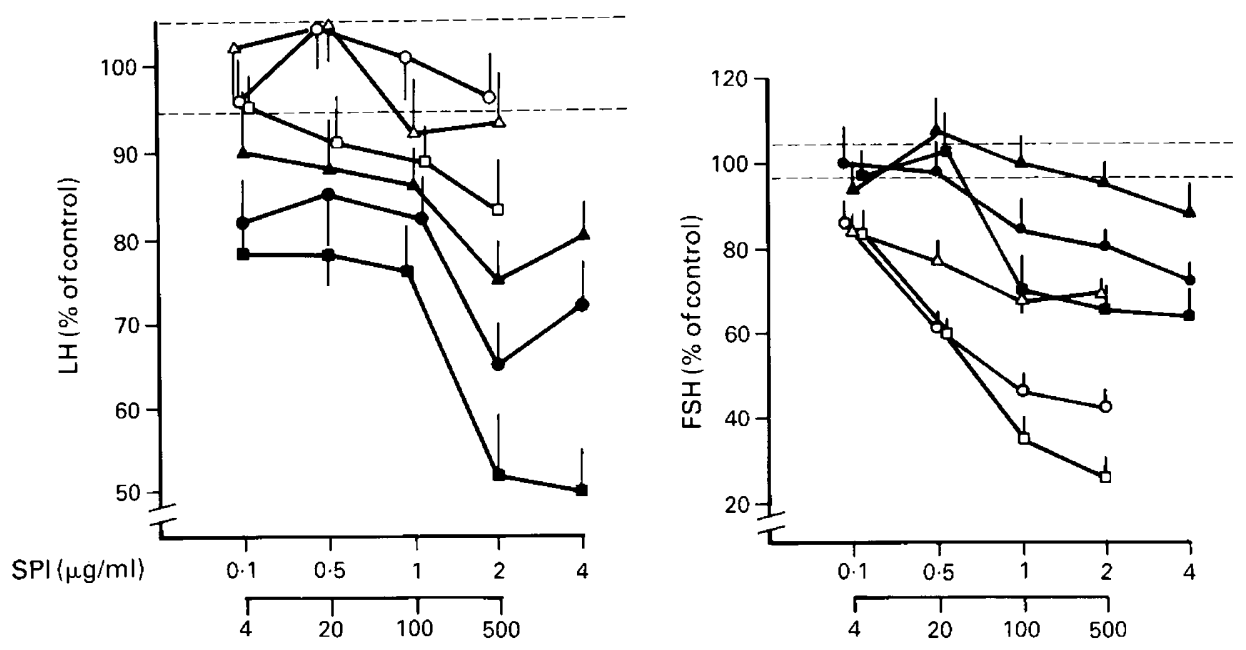

oFF $(\mathrm{nl} / \mathrm{ml})$

Fig. 7. Effect of seminal plasma inhibin-like peptide (SPI) and oFF on gonadotrophin output by pituitary cells from ovariectomized ewes during 3 days of culture. Gonadotrophin output (initially calculated as ng/culture) by treated cultures has been expressed as a percentage of the mean secretion of control (zero dose) cultures which ranged from 30 to $50 \mathrm{ng} \mathrm{FSH} /$ culture, and 250 to $340 \mathrm{ng} \mathrm{LH} / \mathrm{culture}$. Values are the mean percentages of 5 replicate cultures with vertical lines showing the s.e.m. The horizontal dotted line shows the s.e.m. associated with the control (zero dose) cultures. $\boldsymbol{\Delta}, \boldsymbol{\square}$ refer to Days 1, 2 and 3 of culture respectively for SPI treatments and $\triangle, O, \square$ refer to Days 1,2 and 3 of culture respectively for oFF treatments.

\section{Effect of seminal plasma inhibin-like peptide (SPI) on FSH and LH output in vitro}

Figure 7 shows a comparison of the effects of SPI and oFF on FSH and LH output by pituitary cells from ovariectomized ewes. Ovine FF caused a marked dose-dependent suppression of mean FSH output, but had comparatively little effect on mean LH output. SPI had no effect on mean FSH output at doses from $1 \mathrm{pg} / \mathrm{ml}$ to $500 \mathrm{ng} / \mathrm{ml}$. At doses of $\geqslant 1 \mu \mathrm{g} / \mathrm{ml}$ SPI did suppress mean FSH output, although less effectively than oFF, but it also had a marked suppressive effect on mean LH output. The inhibitory effect of 2 and $4 \mu \mathrm{g} \mathrm{SPI} / \mathrm{ml}$ on gonadotrophin output was also accompanied by a marked deterioration in the morphological appearance of the cells which shrank and detached from the culture wells. This toxic effect was also reflected in the cellular protein determined at the end of the culture period. Control (zero dose) cultures had mean \pm s.e.m. protein values of $139 \pm 2 \mu \mathrm{g}$, whereas the values for cultures treated with 2 and $4 \mu \mathrm{g}$ SPI/ml were $83 \pm 2$ and $63 \pm 3 \mu \mathrm{g}$ protein respectively. None of the doses of oFF used, or indeed of any of the above steroids studied, had any significant effect on the mean amount of cellular protein determined at the end of the culture period, relative to their control cultures.

\section{Discussion}

The present study demonstrates that there are marked differences in the way in which FSH and LH output by the sheep pituitary can be manipulated. While LH output can be readily increased with GnRH, FSH output can only be increased marginally by comparison. FSH output is, however, readily susceptible to suppression by FF (most likely reflecting its inhibin activity) and oestradiol$17 \beta$, whereas LH output is more resistant to the suppressive actions of these agents. These findings are consistent with the view that LH output is normally acutely controlled by hypothalamic GnRH 
stimulation, whereas ovarian negative feedback effects normally control FSH output (Martin et al., 1986, 1988).

The observation that GnRH more effectively increased LH than FSH output by cultured sheep pituitary cells is similar to the findings of Huang \& Miller (1980). Stimulation of gonadotrophin output occurred during the first $24-\mathrm{h}$ culture period, but not thereafter. This could be a consequence of effects on the GnRH receptor population of the dissociation procedure used to prepare the cells. Alternatively, it may be the result of 'desensitization' to GnRH, or depletion of 'releasable' pools of gonadotrophin. Similar effects can also occur in vivo. Although a single injection of GnRH will increase mean plasma concentrations of LH and marginally increase mean FSH concentrations (Fig. 2), repeated frequent injections or continuous infusion of GnRH can lead to a decline in plasma gonadotrophin concentrations after an initial stimulation (Fraser et al., 1981; Crowder et al., 1986).

Studies of the suppressive effects of oestradiol-17 $\beta$ and FF on gonadotrophin output were restricted to ewes which had previously been ovariectomized in order to release the pituitary from ovarian negative feedback effects. Oestradiol-17 $\beta$ (or oestradiol benzoate) and FF were very effective individually in suppressing FSH output in vitro and plasma FSH concentrations in vivo, and cumulative suppressive effects were apparent when they were given together (Figs 3-5). After ovariectomy, pituitary gonadotrophin composition appears to be altered, as reflected by an increased half-life for FSH (Fry et al., 1987). It is therefore possible that the effects of oestradiol$17 \beta$ (oestradiol benzoate) and FF on gonadotrophin output in ovariectomized ewes may differ to some extent from their effects in intact ewes. However, suppression of FSH output by oestradiol$17 \beta$ and FF has also been observed previously in intact ewes both in vitro and in vivo (Reeves et al., 1974; Pant, 1977; Henderson et al., 1986, 1988; Tsonis et al., 1986).

The relative contributions of oestradiol-17 $\beta$ and inhibin to the physiological regulation of FSH output in sheep remain unresolved. Although both oestradiol benzoate and FF could individually reduce plasma FSH concentrations in ovariectomized sheep to pre-ovariectomy levels, very high concentrations of each were required (Fig. 5). FSH output in sheep is therefore more likely to be regulated through the observed cumulative effects of oestradiol-17 $\beta$ and inhibin, as has been suggested by the studies of Martin et al. (1988). Although combined treatment with oestradiol benzoate and bFF generally had a cumulative effect in reducing plasma FSH concentrations (Fig. 5), this was not apparent $20 \mathrm{~h}$ after the initial injections when oestradiol benzoate was exerting a positive feedback effect on gonadotrophin output. At this time, combined treatment with oestradiol benzoate negated the reduction in plasma FSH brought about by bFF. This is consistent with the findings of Medhamurthy et al. (1987) for sheep: a bovine follicular fluid inhibin preparation failed to suppress the preovulatory FSH surge, which is initiated by the increasing amounts of oestradiol-17 $\beta$ secreted by the ovary. Previous studies in sheep have demonstrated a transient fall in plasma $\mathbf{L H}$ values within the first $5-12 \mathrm{~h}$ after administration of oestradiol-17 $\beta$ or oestradiol benzoate (Pant, 1977; Fraser et al., 1981; Clarke et al., 1982). The failure to observe suppression of plasma LH with oestradiol benzoate in the present study was probably due to the timing and infrequency of the blood sampling. No effect of oestradiol-17 $\beta$ was observed on LH output in vitro. However, because $\mathrm{LH}$ is normally released in a pulsatile fashion in vivo and is regulated through changes in pulse frequency and amplitude, such modulatory effects may not be readily discernible in a static culture system.

Although oestradiol-17 $\beta$ was effective in suppressing mean FSH output in vitro at doses as low as $1-5 \mathrm{pg} / \mathrm{ml}$, other steroids examined could also suppress FSH output if a sufficiently high dose $(\geqslant 500 \mathrm{pg} / \mathrm{ml})$ was used. Whether the suppression of FSH output found with such high doses reflects a physiological role of the steroids in FSH regulation, or is merely a pharmacological effect is uncertain. The inhibitory effect of progesterone on sheep FSH output in vitro has been demonstrated previously (Batra \& Miller, 1985), although these authors found that androgens had only a minor $(<10 \%$ inhibition) or no effect on FSH output. 
In rats, $3 \alpha$-hydroxy-4-pregnen-20-one has been shown to be extremely potent in selectively suppressing FSH output both in vivo and in vitro; doses of $10 \mathrm{pg} / \mathrm{ml}$ significantly suppress FSH output by rat pituitary cells in vitro (Wiebe \& Wood, 1987). It was therefore felt that this steroid might be potentially useful for manipulating FSH output in sheep. However, in sheep pituitary cell cultures, doses of $\geqslant 500 \mathrm{pg} / \mathrm{ml}$ were required to suppress FSH output and suppression was only observed during the 2 nd and 3rd days of culture (Fig. 6). Such species variation in the action of steroids on pituitary gonadotrophin output has been observed previously (Miller \& Wu, 1981).

Inhibin preparations can be used to manipulate plasma FSH concentrations and increase ovulation rates in sheep, e.g. by repeated injections of bFF (Henderson et al., 1986), or by active immunization with a partly pure inhibin preparation derived from bFF (Henderson et al., 1984; Cummins et al., 1986). Commercial application of such techniques might be encouraged by the availability of large amounts of inexpensive preparations of inhibin. The availability of a synthetic 31 amino acid peptide (seminal plasma inhibin-like peptide) reported to have inhibin activity offered some potential in this regard (Yamashiro et al., 1984; Sairam et al., 1987). However, while 2-6 ng of this peptide reportedly suppressed by $50 \%$ FSH output by mouse pituitaries in vitro, doses from $1 \mathrm{pg} / \mathrm{ml}$ to $500 \mathrm{ng} / \mathrm{ml}$ in the present study had no effect on FSH output by cultured sheep pituitary cells. At higher doses, both LH and FSH output were reduced, but this was accompanied by morphological deterioration of the cells, indicative of a toxic effect. It seems unlikely that this peptide will be useful for specifically manipulating FSH output in sheep. Other studies in rats with this peptide have also failed to demonstrate FSH-suppressing activity either in vivo or in vitro (Liu et al., 1985).

The stimulatory effects of endogenous GnRH in combination with the suppressive effects of endogenous oestradiol-17 $\beta$ and inhibin are probably the major factors which determine the pituitary output of FSH, and hence circulating plasma FSH concentrations. Increases in plasma FSH concentrations could, therefore, be achieved by either increasing the stimulatory effect of GnRH and/or reducing the suppressive effects of oestradiol-17 $\beta$ and/or inhibin. This study demonstrates that exogenous GnRH has comparatively little stimulatory effect on pituitary FSH output compared to its effect on LH output. In contrast, exogenous oestradiol-17 $\beta$ and FF have marked suppressive effects on FSH output. Therefore, the development of pharmacological means to reduce the negative feedback effects of endogenous oestradiol-17 $\beta$ and/or inhibin on FSH output, rather than increasing pituitary exposure to $\mathrm{GnRH}$, might be the more appropriate strategy to raise plasma FSH concentrations selectively, and hence increase ovulation rates in sheep.

We thank the National Institute of Diabetes, Digestive and Kidney Diseases, Bethesda, USA, for providing the ovine gonadotrophins and FSH radioimmunoassay reagents through the National Hormone and Pituitary Program, University of Maryland School of Medicine, Maryland, USA; Dr J. P. Wiebe, University of Western Ontario, Canada for $3 \alpha$ - and $3 \beta$-hydroxy4-pregnen-20-one; Mr G. Aliprantis for assistance in obtaining ovaries from the Wellington abattoir for collection of follicular fluid; and the Wallaceville farm staff for supervision and care of the sheep at Wallaceville.

\section{References}

Batra, S.K. \& Miller, W.L. (1985) Progesterone inhibits basal production of follicle stimulating hormone in ovine pituitary cell culture. Endocrinology 117, 2443-2448.

Clarke, I.J., Funder, J.W. \& Findlay, J.K. (1982) Relationship between pituitary nuclear oestrogen receptors and the release of LH, FSH and prolactin in the ewe. J. Reprod. Fert. 64, 355-363.

Crowder, M.E., Herring, R.D. \& Nett, T.M. (1986) Rapid recovery of gonadotroph function after down regulation of receptors for $\mathrm{GnRH}$ in ewes. J. Reprod. Fert. 62, 131-140.

Cummins, L.J., O'Shea, T., Al-Obaidi, S.A.R., Bindon, B.M. \& Findlay, J.K. (1986) Increase in ovulation rate after immunization of Merino ewes with a fraction of bovine follicular fluid containing inhibin activity. J. Reprod. Fert. 77, 365-372.

Fraser, H.M., Clarke, I.J. \& McNeilly, A.S. (1981) Effect of oestrogen and an LH-RH agonist on the release of 
gonadotrophins in ovariectomized ewes deprived of LH-RH. J. Reprod. Fert. 62, 131-140.

Fry, R.C., Cahill, L.P., Cummins, J.T., Bindon, B.M., Piper, L.P. \& Clarke, I.J. (1987) The half-life of follicle-stimulating hormone in ovary-intact and ovariectomized Booroola and control Merino ewes. J. Reprod. Fert. 81, 611-615.

Henderson, K.M. \& McNatty, K.P. (1987) Factors influencing ovulation rate in sheep. In Proceedings of the 4th Animal Science Congress of the AsianAustralasian Association of Animal Production Societies, pp. 130-133. Hamilton, New Zealand.

Henderson, K.M., Franchimont, P., Lecomte-Yerna, M.J., Hudson, N. \& Ball, K. (1984) Increase in ovulation rate after active immunization of sheep with inhibin partially purified from bovine follicular fluid. J. Endocr. 102, 305-309.

Henderson, K.M., Prisk, M.D., Hudson, N., Ball, K., McNatty, K.P., Lun, S., Heath, D., Kieboom, L.E. \& McDiarmid, J. (1986) Use of bovine follicular fluid to increase ovulation rate or prevent ovulation in sheep. J. Reprod. Fert. 76, 623-635.

Henderson, K.M., Savage, L.C., Ellen, R.L., Ball, K. \& McNatty, K.P. (1988) Consequences of increasing or decreasing plasma FSH concentrations during the preovulatory period in Romney ewes. $J$. Reprod. Fert. 84, 187-196.

Huang, E.S-R. \& Miller, W.L. (1980) Effects of estradiol$17 \beta$ on basal and luteinizing hormone releasing hormone-induced secretion of luteinizing hormone and follicle stimulating hormone by ovine pituitary cell culture. Biol. Reprod. 23, 124-134.

Liu, L., Booth, J., Merriam, G.R., Barnes, K.M., Sherins, R.J., Loriaux, D.L. \& Cutler, G.B. (1985) Evidence that synthetic 31 -amino acid inhibin-like peptide lacks inhibin activity. Endocrine Res. 11, 191-197.

Lowry, O.H., Rosebrough, N.J., Farr, A.L. \& Randall, R.S. (1951) Protein measurement with the Folin phenol reagent. J. biol. Chem. 193, 265-275.

Martin, G.B. (1984) Factors affecting the secretion of luteinizing hormone releasing hormone in the ewe. Biol. Rev. 59, 1-87.

Martin, G.B., Wallace, J.M., Taylor, P.L., Fraser, H.M., Tsonis, C.G. \& MeNeilly, A.S. (1986) The roles of inhibin and gonadotrophin-releasing hormone in the control of gonadotrophin secretion in the ewe. $J$. Endocr. 111, 287-296.

Martin, G.B., Price, C.A., Thiery, J-C. \& Webb, R. (1988) Interactions between inhibin, oestradiol and progesterone in the control of gonadotrophin secretion in the ewe. J. Reprod. Fert. 82, 319-328.

McNatty, K.P., Gibb, M., Dobson, C. \& Thurley, D.C. (1981a) Evidence that changes in luteinizing hormone secretion regulate the growth of the preovulatory follicle in the ewe. J. Endocr. 90, 375-389.

McNatty, K.P., Gibb, M., Dobson, C., Thurley, D.C. \& Findlay, J.K. (1981b) Changes in the concentrations of gonadotrophin and steroidal hormones in the antral fluid of ovarian follicles throughout the oestrous cycle of the sheep. Aust. J. biol. Sci, 34, $67-80$.

McNatty, K.P., Hudson, N., Gibb, M., Ball, K., Henderson, K.M., Heath, D.A., Lun, S. \& Kieboom, L.E. (1985) FSH influences follicle viability oestradiol biosynthesis and ovulation rate in Romney ewes. J. Reprod. Fert. 75, 121-131.

McNatty, K.P., Fisher, M., Collins, F., Hudson, N.L., Heath, D.A., Ball, K. \& Henderson, K.M. (1989) Differences in the plasma concentrations of FSH and $\mathrm{LH}$ in ovariectomized Booroola $\mathrm{FF}$ and ++ ewes. J. Reprod. Fert. 85, 705-713.

Medhamurthy, R., Carruthers, T.D. \& Manns, J.G. (1987) Effect of bovine follicular fluid inhibin on serum gonadotrophin concentrations in ewes during oestrus. J. Reprod. Fert. 81, 91-98.

Miller, W.L. \& Wu, J. (1981) Estrogen regulation of follicle stimulating hormone production in vitro: species variation. Endocrinology 108, 673-679.

Montgomery, G.W., Martin, G.B., Blanc, M.R. \& Pelletier, J. (1987) Season influences FSH concentration in ovariectomized Ile-de-France ewes. $J$. Reprod. Fert. 80, 271-277.

Pant, H.C. (1977) Effects of oestradiol infusion on plasma gonadotrophins and ovarian activity in progesterone-primed and unprimed anoestrous ewes. J. Endocr. 75, 227-233.

Radford, H.M., Avenell, J.A. \& Szell, A. (1984) Human chorionic gonadotrophin induces multiple ovulation in sheep. In Reproduction in Sheep, pp. 342-344. Eds D. R. Lindsay \& D. T. Pearce. Australian Academy of Science, Canberra.

Reeves, J.J., Beck, T.W. \& Nett, T.M. (1974) Serum FSH in anestrous ewes treated with $17 \beta$-estradiol. $J$. Anim. Sci. 38, 374-377.

Sairam, M.R., Ramasharma, K. \& Li, C.H. (1987) Synthetic peptide with inhibin-like activity preferentially inhibits follitropin secretion in comparison with lutropin-releasing hormone antagonists. Proc. natn. Acad. Sci. USA 84, 2043-2046.

Tsonis, C.G., McNeilly, A.S. \& Baird, D.T. (1986) Measurement of exogenous and endogenous inhibin in sheep serum using a new and extremely sensitive bioassay for inhibin based on inhibition of ovine pituitary FSH secretion in vitro. $J$. Endocr. 110, 341-352.

Wiebe, J.P, \& Wood, P.H. (1987) Selective suppression of follicle stimulating hormone by $3 \alpha$-hydroxy-4pregnen-20-one, a steroid found in Sertoli cells. Endocrinology 120, 2259-2264.

Yamashiro, D., Li, C.H., Ramasharma, K. \& Sairam, M.R. (1984) Synthesis and biological activity of human inhibin-like peptide (1-31). Proc. natn. Acad. Sci. USA 81, 5399-5402.

Received 5 July 1988 